\title{
Fiscal Policy in a Floating Exchange Rate Regime with Consumption Home Bias
}

\author{
Chung-Fu Lai ${ }^{1} \&$ Wen-Fang Wang ${ }^{1}$ \\ ${ }^{1}$ Department of Applied Economics, Fo Guang University, Yilan County, Taiwan \\ Correspondence: Chung-Fu Lai, Department of Applied Economics, Fo Guang University, No. 160, Linwei Rd., \\ Jiaosi, Yilan County 26247, Taiwan (R.O.C.). Tel: 886-3-987-1000. E-mail: cflai@ gm.fgu.edu.tw
}

Received: March 1, 2016

Accepted: March 11, 2016

Online Published: May 25, 2016

doi:10.5539/ijef.v8n6p24

URL: http://dx.doi.org/10.5539/ijef.v8n6p24

\begin{abstract}
This paper presents New Open Economy Macroeconomics as the analytical framework in attempt to explore the long term effects of fiscal expenditure shocks on various macroeconomic variables (e.g. consumption, output, prices, exchange rate, terms of trade), and tries to explain the role that consumption home bias plays. With theoretical derivation and simulation analysis, we find that in the long-term, an increasing in fiscal spending will cause rise of domestic output, domestic price index and the exchange rate, but it will crowd out domestic private consumption, the relationship between fiscal spending and the terms of trade, which is depending on asymmetry of consumption bias behavior of consumers between countries.
\end{abstract}

Keywords: fiscal policy, consumption home bias, micro-foundation, new open economy macroeconomics

\section{Introduction}

According to Keynesian school, it convinced that the fiscal policy is an effective counter-cyclical means. In fact, with government itself highlighting the role of economic regulation, it also is very positive on the operation of fiscal policy. Every school has quite different view on the effects of fiscal policy on output, consumption, interest rates and prices. In terms of government spending, Keynesian school considered that the expansion of government spending will increase output, leaving the private investment to increase, but on the one hand, the rising prices and interest rates will crowd out investment of private sector, so, it is uncertain to judge the effects of government spending on private investment, as for the consumption by private sectors, it must depend on the size of the marginal propensity, and how it respond to the interest rate. Classical school thought that fiscal policy only affects nominal variables, and it does not affect the real variables, the increased government spending only cause rise of prices. In addition, Neoclassical school emphasized the temporary and permanent government spending have different effects on macro economy. In addition, Supply-side school preferred tax cut policy, convincing that it may increase labor incentives, savings and investment, directly stimulating increase of aggregate supply to reduce inflation of price and unemployment. The effects of fiscal policy on macroeconomic variables, whether in theoretical or empirical aspect, is showing a great difference. In addition, exchange rate represents relative prices of domestic and foreign currency assets, which bearing the important task of connecting domestic and international economy, and modulating internal and external balance of economy. Therefore, this paper explored the effects of fiscal policy under the floating exchange rate regime.

The initial development of open economy analysis is Mundell-Fleming model (see Mundell, 1963; Fleming, 1962) and Dornbusch (1976) model which was extended mainly by Keynes as the theoretical basis, although such early open economy model reveals and explains the relationship among some major macroeconomic variables, there was a common defect, namely, was lack of micro-foundation. Lucas (1976) suggested that the changes in the macroeconomic variables can affect individual decisions on micro economy, thereby causing overall change in the relationship among economic variables, resulting in bias generated by a lack of micro-foundation. So, New Open Economy Macroeconomics (hereinafter referred to as NOEM) further opens a new stage of macroeconomics, NOEM is proposed by Obstfeld and Rogoff (1995), which is characterized by both with micro-foundation and monopolistic competition market structure, is very suitable for analyzing the effects of exogenous shocks on macroeconomic variables, therefore, this paper uses NOEM as the basis for analysis.

No matter theoretical or empirical literature, they have difference in the conclusion made on the effects of fiscal 
policy on macro economy, especially that the effects of fiscal policy on macroeconomic variables (such as private consumption, private investment, real wages and employment) is not consistent. In the theoretical literature, the Real Business Cycle model proposed by Baxter and King (1993) assumed household with indefinite life, wherein its consumption decision is limited by intertemporal budget constraint equation. When government spending increases and incorporated with lump-sum taxes, the present value of after-tax income will be reduced, resulting in a negative wealth effect reducing consumption, and under a given wage level, labor supply increases. In equilibrium, the real wages fell, employment rose and output increased. If the employment continued to increase enough, it will raise the marginal productivity of capital, resulting in increased investment (see Galí et al., 2007). In contrast, the consumption of the household withtraditional IS-LM model is a function of current disposable income, instead of lifetime income function. Therefore, an increase in government spending will cause consumption to increase, and in the assumption that the money supply is fixed, a corresponding rise will occur in short-term nominal interest rates, thereby, private investment will fell.

From the foregoing statement, research made on the effects of fiscal policy on macro economy mostly focused in a closed economy (such as Barro, 1990; Futagami et al., 1993; Devereux \& Love, 1995; Greiner, 1998; Greiner \& Hanusch, 1998; Dasgupta, 1999 and Xie et al., 1999, etc.), and the analysis in topic of the effects of fiscal policy in an open economy is relatively rare, until recently, with the rapid emerge of literature titled "NOEM", such as literatures of Corsetti and Pesenti (2001), Ganelli (2003) and Pitterle and Steffen (2004a; 2004b), had made the topic of research on the effects of fiscal policy extend to open economy aspect. However, in the conventional NOEM model, the main reason causing exchange rate fluctuations is private consumption behavior, therefore, the subject triggering this paper to be attractive is, if we further assumed that consumer behavior also includes the consumption behavior of government, and no matter the consumption behavior of individual or government exists consumption home bias, what will be the result? So, the purpose of this paper is to explore the correlation among government expenditure, consumption home bias and macroeconomic variables. Tervala (2008) had ever analyzed the effects of fiscal policy at NOEM architecture, the findings demonstrated that the marginal rate of substitution behind individual and government consumption is the main reason that fiscal expenditure affecting the welfare effect, however, it ignored a hot topic recently discussed-consumption home bias.

Although Obstfeld and Rogoff (2000) have deemed "home bias in consumption puzzle" as one of six puzzles of international economics, (Note 1) under the NOEM framework, the role that asymmetry of "consumption home bias" plays is still lack of complete research analysis, which is the direction this paper further to seek breakthrough. The so-called consumption home bias puzzle means that consumers have tendency to prefer domestic goods in the real world, but, this phenomenon cannot be explained by researchers in real market. In the studies made on the topic of consumption home bias, they mostly focused on the early exploration of the causes of consumption home bias, such as trade costs (Obstfeld \& Rogoff, 2000; Ried, 2009), country size and openness (Sutherland, 2005; De Paoli, 2009), non-traded goods (Stockman \& Dellas, 1989; Pesenti \& Van Wincoop, 2002) as well as trade in intermediate input factors (Hillberry \& Hummels, 2002), all are main causes that scholars believe to constitute consumption home bias. More recent studies have focused on discussion on the effect of consumption home bias, such as Pierdzioch (2004) analyzed the effect of monetary shock on different home bias and the extent of capital mobility, Hau (2002), Pitterle and Steffen (2004a; 2004b), Kollmann (2004), Sutherland (2005), Leith and Lewis (2006) and Cooke (2010) discussed the effect of home bias on exchange rate fluctuations, De Paoli (2009) discussed the welfare effects of home bias and monetary policy. In addition, it worth mentioning that the effect of home bias on the optimal monetary policy is quite a hot topic recently, which including research made by Faia and Monacelli (2006), Jondeau and Sahuc (2008), Galí and Monacelli (2008) and Wang (2010); obviously, the studies made in respect of consumption home bias were quite enthusiastic, but none of literature up to now can clearly explain the role of home bias on the effects of government expenditure shock.

This paper divided into four sections. Except for the introduction, the other sections are arranged as follows: Section 2 constructs a theoretical model; Section 3 makes the simulation analysis for exploration on the long-term effects of government spending on the macroeconomic variables and the role of consumption home bias; Section 4 includes conclusions and recommendations.

\section{Theoretical Model}

\subsection{Model Setting}

This paper follows NOEM model proposed by Obstfeld and Rogoff (1995) as the theoretical basis, the main assumptions are as follows: 
1) There are two countries in the world: "home country" and "foreign country". Hereunder, all the foreign economic variables are marked with "**".

2) The population in the world is distributed between intervals of $[0,1]$, where domestic individuals are distribution in $[0, n)$, and foreign individuals are distributed in $[n, 1]$.

3) Each individual is both consumer and producer, operating a monopoly competitor factory and using labor for production.

4) Consumption home bias exists in the economy system and fiscal policy is the only one exogenous shock.

\subsubsection{Household}

Assuming that all individuals have the same preferences, utility $(U)$ and consumption $(C)$ and real money balances $(M / P)$ are in positive proportional, and is inversely proportional to the output $(y)$, wherein, the lifetime utility function is set as follows:

$$
U_{t}=\sum_{s=t}^{\infty} \beta^{s-t}\left[\log C_{s}+\frac{\chi}{1-\varepsilon}\left(\frac{M_{s}}{P_{s}}\right)^{1-\varepsilon}-\frac{\kappa}{2} y_{s}(z)^{2}\right], \quad \varepsilon>0
$$

Where $\beta$ is the discount factor $(0<\beta<1), \varepsilon$ is the elasticity of marginal utility of real money balances, (Note 2) $\chi$ and $\kappa$ represent the degree of significance of real money balances and output on the utility function, $z$ refers to a particular product.

In Eq. (1), define the consumption index of consumer as the function of constant elasticity of substitution (CES):

$$
C_{t}=\left[\int_{0}^{n} \alpha^{\frac{1}{\delta}} c_{h, t}(z)^{\frac{\delta-1}{\delta}} d z+\int_{n}^{1}(1-\alpha)^{\frac{1}{\delta}} c_{f, t}(z)^{\frac{\delta-1}{\delta}} d z\right]^{\frac{\delta}{\delta-1}}, \delta>1
$$

Where $c_{h}(z)$ is the consumption of domestic consumers for domestic specific products $\mathrm{Z}, c_{f}(z)$ is the consumption of domestic consumers for foreign specific product $\mathrm{Z}, \alpha$ is the consumption home bias parameters to measure the degree of domestic consumers preferring domestic goods, and $\delta$ is the elasticity of substitution of goods between two countries.

Based on Eq. (2), domestic price index $(P)$ can be derived under the problem of expenditure minimization as:

$$
P_{t}=\left[\int_{0}^{n} \alpha p_{h, t}(z)^{1-\delta} d z+\int_{n}^{1}(1-\alpha) p_{f, t}(z)^{1-\delta} d z\right]^{\frac{1}{1-\delta}}
$$

Likewise, the foreign price index $\left(P^{*}\right)$ is as follows:

$$
P_{t}^{*}=\left[\int_{0}^{n}\left(1-\alpha^{*}\right) p_{h, t}^{*}(z)^{1-\delta} d z+\int_{n}^{1} \alpha^{*} p_{f, t}^{*}(z)^{1-\delta} d z\right]^{\frac{1}{1-\delta}}
$$

In the above two equations, $p_{h}(z)$ represents the price expressed with domestic currency for domestic commodity $z, p_{f}(z)$ represents domestic currency price of foreign commodity $z, p_{h}^{*}(z)$ represents that the foreign currency price of domestic commodity $z ; p_{f}^{*}(z)$ represents the foreign currency price of foreign commodity $z, \alpha^{*}$ represents the degree of foreign consumers preferring foreign goods.

For any product, the law of one price is stated as follows: 


$$
\begin{aligned}
& p_{h, t}(z)=E_{t} p_{h, t}^{*}(z) \\
& p_{f, t}(z)=E_{t} p_{f, t}^{*}(z)
\end{aligned}
$$

Where $E$ represents the exchange rate.

From Eqs. (2) and (3), we can respectively derive consumption of domestic representative consumer on domestic and foreign specific commodities as follows:

$$
\begin{gathered}
c_{h, t}(z)=\left(\frac{\alpha p_{h, t}(z)}{P}\right)^{-\delta} C \\
c_{f, t}(z)=\left(\frac{(1-\alpha) p_{f, t}(z)}{P}\right)^{-\delta} C
\end{gathered}
$$

Likewise, the consumption that foreign representative consumer on domestic and foreign specific commodity as follows:

$$
\begin{gathered}
c_{h, t}^{*}(z)=\left(\frac{\left(1-\alpha^{*}\right) p_{h, t}^{*}(z)}{P^{*}}\right)^{-\delta} C^{*} \\
c_{f, t}^{*}(z)=\left(\frac{\alpha^{*} p_{f, t}^{*}(z)}{P^{*}}\right)^{-\delta} C^{*}
\end{gathered}
$$

In both equations as above, $c_{h}^{*}(z)$ represents the consumption that foreign consumers for domestic specific product, while $c_{f}^{*}(z)$ represents the consumption that foreign consumers for foreign specific product.

\subsubsection{Government}

Suppose that government uses seignorage and lump-sum tax revenue to finance expenditure, hence the government budget constraint is:

$$
G_{t}=T_{t}+\frac{M_{t}-M_{t-1}}{P_{t}}
$$

Where the left hand side of equation refers to real government expenditure, while the first item on the right of the equation refers to real tax revenue and the second item on the right of the equation is real seigniorage revenue.

Suppose that government and private sectors have the same preferences, the function of government expenditure shall be also CES, that is:

$$
G_{t}=\left[\int_{0}^{n} \alpha^{\frac{1}{\delta}} g_{h, t}(z)^{\frac{\delta-1}{\delta}} d z+\int_{n}^{1}(1-\alpha)^{\frac{1}{\delta}} g_{f, t}(z)^{\frac{\delta-1}{\delta}} d z\right]^{\frac{\delta}{\delta-1}}
$$

Where $g_{h}(z)$ represents the consumption of domestic government sector on domestic specific goods $z, g_{f}(Z)$ represents domestic government's consumption on foreign specific goods $z$.

\subsubsection{Asset Market}

Suppose that there is an integrated international capital markets between two countries, and each individual can trade real bonds $(B)$ in this international capital market, and the relationship between real interest rate $(r)$ and nominal interest rate $(i)$ of maturing bonds is as shown in Fisher equation, namely:

$$
1+i_{t}=\frac{P_{t+1}}{P_{t}}\left(1+r_{t}\right)
$$


Holding bonds reflects the lending relationship between the residents of two countries, thus satisfying $n B_{t}+(1-n) B_{t}^{*}=0$, or

$$
B_{t}^{*}=-\frac{n}{1-n} B_{t}
$$

Where $B_{t}$ refers to the amount of bonds held by domestic representative individual and $B_{t}{ }^{*}$ refers to that held by foreign representative individual.

\subsubsection{Budget Constraint}

Budget constraints equation of representative individual is set as follows:

$$
M_{t}+P_{t} C_{t}+P_{t} B_{t}=M_{t-1}+P_{t}\left(1+r_{t-1}\right) B_{t-1}+p_{h, t}(z) y_{h, t}(z)-P_{t} T_{t}
$$

In the equation, consumer's source of income in period $t$ includes: the balance of the money in period $t-1$ $\left(M_{t-1}\right)$, the sum of principal and interest of bonds $\left(P_{t}\left(1+r_{t-1}\right) B_{t-1}\right)$, and output revenue $\left(p_{h, t}(z) y_{h, t}(z)\right)$, consumers can use the income of period $t$ to hold money $\left(M_{t}\right)$, consumption $\left(P_{t} C_{t}\right)$, bonds purchases $\left(\left(P_{t} B_{t}\right)\right)$ and taxes payment $\left(P_{t} T_{t}\right)$.

\subsubsection{Aggregate Demand}

From Eqs. (7) and (9), demand on the goods that domestic manufacturers face can be expressed as:

$$
\begin{aligned}
& y_{h, t}(z)=n\left(c_{h, t}(z)+g_{h, t}(z)\right)+(1-n)\left(c_{h, t}^{*}(z)+g_{h, t}^{*}(z)\right) \\
= & n\left(\frac{\alpha p_{h, t}(z)}{P}\right)^{-\delta}\left(C_{t}+G_{t}\right)+(1-n)\left(\frac{\left(1-\alpha^{*}\right) p_{h, t}^{*}(z)}{P^{*}}\right)^{-\delta}\left(C_{t}^{*}+G_{t}^{*}\right)
\end{aligned}
$$

Where $G^{*}$ refers to the consumption of foreign government sector.

Likewise, Eqs. (8) and (10), demand on the goods that foreign manufacturers face can be expressed as:

$$
\begin{gathered}
y_{f, t}^{*}(z)=n c_{f, t}(z)+(1-n) c_{f, t}^{*}(z) \\
=n\left(\frac{(1-\alpha) p_{f, t}(z)}{P}\right)^{-\delta}\left(C_{t}+G_{t}\right)+(1-n)\left(\frac{\alpha^{*} p_{f, t}^{*}(z)}{P^{*}}\right)^{-\delta}\left(C_{t}^{*}+G_{t}^{*}\right)
\end{gathered}
$$

\subsubsection{First Order Conditions}

Under the budget constraint (Eq. (14)), the first-order conditions of utility (Eq. (1)) maximization is expressed as:

$$
\begin{gathered}
C_{t+1}=\beta\left(1+r_{t}\right) C_{t} \\
\frac{M_{t}}{P_{t}}=\left(\frac{\left(1+i_{t}\right) \chi}{i_{t}} C_{t}\right)^{\frac{1}{\delta}} \\
{\left[y_{t}(z)\right]^{\frac{\delta+1}{\delta}}=\left(\frac{\delta-1}{k \delta}\right) C_{t}^{-1}\left(C_{t}^{W}+G_{t}^{W}\right)^{\frac{1}{\delta}}}
\end{gathered}
$$

Where Eq. (17) is Euler equation of consumption, which describes intertemporal consumption behavior, Eq. (18) is money demand equation for indicating the substitution relationship between real money demand and consumption, Eq. (19) refers to the labor supply equation, which gives the alternative relationship between labor supply and consumption, in the equation, $C^{W}$ represents world private consumption, $C_{t}^{W} \equiv n C_{t}+(1-n) C_{t}^{*}$, 
$G^{W}$ represents world government consumption, $G_{t}^{W} \equiv n G_{t}+(1-n) G_{t}^{*}$.

\subsection{Derivation of Steady-State}

The following sections discussed the effects of fiscal policy on every macroeconomic variables. Firstly, given that the economic system does not exist consumption home bias behavior and fiscal expenditure shock was not served in the initial state ( 0 steady state) as a baseline, then to seek a long-term steady state of economy system. The following symbols, the subscript " $\mathrm{t}$ " represents the macroeconomic variables in the long-term steady state, and the subscript "0" represents the macroeconomic variables in the initial state. For example: $C_{t}$ and $C_{0}$ represents the consumption in the long-term steady state and initial state respectively.

Long-term steady state describes that the entire economic system reaches the convergence state after going through exogenous shocks. In the long-term steady state, all variables are fixed, and $B_{t}=B_{t+1}=0$. Therefore, when we apply the government's budget constraint (Eq. (11)) into private sector's budget constraints (Eq. (14)), we can get:

$$
C_{t}=-\hat{B}_{t}+\frac{\left.p_{h, t}(z) y_{h, t}(z)\right)}{P_{t}}-\hat{G}_{t}
$$

Likewise, for foreign aspect, we have:

$$
C_{t}^{*}=-\hat{B}_{t}+\frac{p_{f, t}^{*}(z) y_{f, t}^{*}(z)}{P_{t}^{*}}-\hat{G}_{t}^{*}
$$

\subsection{Log-Linearization}

In order to obtain a closed-form solution, this paper uses approach proposed by Uhlig (1995). Firstly, we put model in log-linearization, then to assign values to the parameters of the model to perform simulation analysis. (Note 3) Below we will put all variables in the vicinity of the initial state into log-linearization to obtain the degree of each variable fluctuates. In this paper, the superscript " $\wedge$ " means the variable carrying out log-linearization.

For example: If $\hat{X}_{t}$ is the result of the variable $X_{t}$, performing log-linearization in the initial state $\left(X_{0}\right)$, then:

$$
\hat{X}_{t} \equiv \ln \frac{X_{t}}{X_{0}} \cong \frac{X_{t}-X_{0}}{X_{0}} \cong \frac{d X_{t}}{X_{0}}
$$

\subsubsection{Log-linearization of Price Index}

Apply Eqs (5) and (6) into Eq. (3) and (4), and put into log-linearization to obtain:

$$
\begin{gathered}
\hat{P}_{t}=n \alpha \hat{p}_{h, t}(z)+(1-n)(1-\alpha)\left(\hat{E}_{t}+\hat{p}_{f, t}^{*}(z)\right) \\
\hat{P}_{t}^{*}=n\left(1-\alpha^{*}\right)\left(\hat{p}_{h, t}(z)-\hat{E}_{t}\right)+(1-n) \alpha^{*} \hat{p}_{f, t}^{*}(z)
\end{gathered}
$$

Subtract Eq. (23) from Eq. (22) to obtain difference between fluctuations of price indices of two countries:

$$
\hat{P}_{t}-\hat{P}_{t}^{*}=n\left(\alpha-\left(1-\alpha^{*}\right)\right) p_{h, t}(z)+\left((1-n)(1-\alpha)+n\left(1-\alpha^{*}\right)\right) \hat{E}_{t}+(1-n)\left((1-\alpha)-\alpha^{*}\right) p_{f, t}^{*}(z)
$$

2.3.2 Log-Linearization of the Law of One Price

Give Eqs. (5) and (6) the process of log-linearization, and get the following equations:

$$
\begin{aligned}
& \hat{p}_{h, t}(z)=\hat{E}_{t}+\hat{p}_{h, t}^{*}(z) \\
& \hat{p}_{f, t}(z)=\hat{E}_{t}+\hat{p}_{f, t}^{*}(z)
\end{aligned}
$$

\subsubsection{Log-Linearization of World Budget Constraint}

Based on Eqs. (20) and (21), the world budget constraint is obtained as follows: 


$$
C_{t}^{W}=n C_{t}+(1-n) C_{t}^{*}=n \frac{p_{h, t}(z) y_{h, t}(z)}{P_{t}}+(1-n) \frac{p_{f, t}^{*}(z) y_{f, t}^{*}(z)}{P_{t}^{*}}-G_{t}^{W}
$$

Put Eq. (27) into log-linearization and use Eqs. (25) and (26) to get:

$$
\hat{C}_{t}^{W}=n\left(\hat{p}_{h, t}(z)+\hat{y}_{h, t}(z)-\hat{P}_{t}\right)+(1-n)\left(\hat{p}_{f, t}^{*}(z)+\hat{y}_{f, t}^{*}(z)-\hat{P}_{t}^{*}\right)-\hat{G}_{t}^{W}
$$

\subsubsection{Log-Linearization of Demand Function}

Put domestic and foreign demand functions (Eqs. (15) and (16)) into log-linearization to get:

$$
\begin{aligned}
& \hat{y}_{h, t}(z)=-\delta\left(n \alpha\left(\hat{p}_{h, t}(z)-\hat{P}_{t}\right)+(1-n)\left(1-\alpha^{*}\right)\left(\hat{p}_{h, t}^{*}(z)-\hat{P}_{t}^{*}\right)\right)+\hat{C}_{t}^{W}+\hat{G}_{t}^{W} \\
& \hat{y}_{f, t}^{*}(z)=-\delta\left(n(1-\alpha)\left(\hat{p}_{f, t}(z)-\hat{P}_{t}\right)+(1-n) \alpha^{*}\left(\hat{p}_{f, t}^{*}(z)-\hat{P}_{t}^{*}\right)\right)+\hat{C}_{t}^{W}+\hat{G}_{t}^{W}
\end{aligned}
$$

\subsubsection{Log-Linearization of Labor Supply Function}

Give Eq. (19) the log-linearization process to obtain the following equation:

$$
(1+\delta) \hat{y}_{h, t}(z)=-\delta \hat{C}_{t}+\hat{C}_{t}^{W}+\hat{G}_{t}^{W}
$$

Similarly, for foreign country, we have:

$$
(1+\delta) \hat{y}_{f, t}^{*}(z)=-\delta \hat{C}_{t}^{*}+\hat{C}_{t}^{W}+\hat{G}_{t}^{W}
$$

\subsubsection{Log-Linearization of Money Demand Function}

Give Eq. (18) the log-linearization process to obtain the following equation:

$$
\hat{M}_{t}-\hat{P}_{t}=\frac{1}{\varepsilon} \hat{C}_{t}
$$

Likewise, for foreign country, we have:

$$
\hat{M}_{t}^{*}-\hat{P}_{t}^{*}=\frac{1}{\varepsilon} \hat{C}_{t}^{*}
$$

Subtract Eq. (34) from Eq. (33) and put it into log-linearization, also use Eq. (24) to get the following relationship equation:

$$
\begin{gathered}
\left((1-n)(1-\alpha)+n\left(1-\alpha^{*}\right)\right) \hat{E}_{t}=\hat{M}_{t}-\hat{M}_{t}^{*}-\frac{1}{\varepsilon}\left(\hat{C}_{t}-\hat{C}_{t}^{*}\right)-n\left(\alpha-\left(1-\alpha^{*}\right)\right) p_{h, t}(z) \\
-(1-n)\left((1-\alpha)-\alpha^{*}\right) p_{f, t}^{*}(z)
\end{gathered}
$$

\subsubsection{Log-Linearization of Terms of Trade}

Define the terms of trade (TOT) as the ratio of export price to import price of the commodity, namely:

$$
T O T=\frac{p_{h, t}(z)}{E_{t} p_{f, t}^{*}(z)}
$$

Put the foregoing equation into log-linearization to get:

$$
T \hat{O} T=\hat{p}_{h, t}(z)-\hat{E}_{t}-\hat{p}_{f, t}^{*}(z)
$$

\subsection{Steady-State Solution}

The Eqs (20) and (21) are given the log-linearization process to obtain the following equations:

$$
\hat{C}_{t}=\hat{p}_{h, t}(z)+\hat{y}_{h, t}(z)-\hat{P}_{t}-\hat{G}_{t}
$$




$$
\hat{C}_{t}^{*}=\hat{p}_{f, t}^{*}(z)+\hat{y}_{f, t}^{*}(z)-\hat{P}_{t}^{*}-\hat{G}_{t}^{*}
$$

We will seek solution of a total of 13 simultaneous equations, including the price index after log-linearization (Eqs. (22) and (23)), law of one price after log-linearization (Eqs. (25) and (26)), the world consumption equation after log-linearization (Eq. (28)), domestic and foreign demand function after log-linearization (Eqs. (29) and (30)), domestic and foreign labor supply function after log-linearization (Eqs. (31) and (32)), domestic and foreign currency demand function subtraction equation after log-linearization (Eq. (35)), the terms of trade after log-linearization (Eq. (36)) and domestic and foreign private budget constraints equation after log-linearization (Eqs. (37) and (38) ) to get correlation equation between 13 endogenous and exogenous variables, the 13 endogenous includes domestic consumption $\left(\hat{C}_{t}\right)$, foreign consumption $\left(\hat{C}_{t}^{*}\right)$, the world consumption $\left(\hat{C}_{t}^{W}\right)$, domestic output $\left(\hat{y}_{h, t}(z)\right)$, foreign output $\left(\hat{y}_{f, t}^{*}(z)\right)$, domestic prices of particular product domestically $\left(\hat{p}_{h, t}(z)\right)$, foreign prices of particular product domestically $\left(\hat{p}_{h, t}^{*}(z)\right)$, foreign prices of particular product in a foreign country $\left(\hat{p}_{f, t}^{*}(z)\right)$, domestic prices of a specific product in a foreign country $\left.\left(\hat{p}_{f, t}(z)\right)\right)$, the exchange rate $\left(\hat{E}_{t}\right)$, domestic price index $\left(\hat{P}_{t}\right)$, foreign price index $\left(\hat{P}_{t}^{*}\right)$ and the terms of trade $(T \hat{O} T)$.

\section{The Effects of Government Spending Shocks on Macroeconomic Variables}

In order to capture the effects of parameter change in consumption home bias on fiscal expenditure shocks, this paper conducted a simulation analysis.

\subsection{Parameterisation}

In order to simplify the analysis in this paper, on NOEM basis, we set two economic systems with equivalent size as the subjects of analysis, so, on the selection of the parameter, we try best to introduce empirical data on the United States and countries with similar scale (such as OECD nations, the European Union) to analyze the effects of fiscal expenditure shock between the United States or other countries with similar size. Firstly, we follow setting mode of Bergin et al (2007) to set the elasticity of substitution of goods between countries $(\delta)$ to 5 , besides, we follow practices of related literature submitted by Mankiw and Summers (1986) and Schmidt (2006) and set the elasticity of marginal utility of real money balance $(\varepsilon)$ to 1 , then adopt the consumption home bias parameter set by Wang (2010) $(\alpha=0.85)$, also simulate circumstances without consumption home bias $(\alpha=0.5)$ and with bias to foreign product ( $\alpha=0.15$ ), the parameter of bias degree that foreign country has on domestic and foreign goods is also the same as that of consumption bias parameter in the home country. Due to other domestic (foreign) exogenous variables other than the domestic fiscal expenditure shock $(\hat{G})$, such as domestic money supply $(\hat{M})$, foreign money supply $\left(\hat{M}^{*}\right)$, and foreign fiscal expenditure shock $\left(\hat{G}^{*}\right)$, were not the focus of discussion in this paper, let's assume that its change rate is 0 , and parameter settings are sorted out as shown in Table 1.

Table 1. Selection of parameters

\begin{tabular}{ccc}
\hline Symbol & Meaning & Value \\
\hline$n$ & Country size & 0.5 \\
$\delta$ & Elasticity of substitution of product between countries & 5 \\
$\varepsilon$ & Elasticity of marginal utility of the real money balances & 1 \\
$\alpha$ & Consumption bias of the home country & $0.15 ; 0.5 ; 0.85$ \\
$\alpha^{*}$ & Consumption bias of the foreign country & $0.15 ; 0.5 ; 0.85$ \\
\hline
\end{tabular}

\subsection{Simulation and Comparative Static Analysis}

In this section, parameter settings of the preceding section were used in the simulation to discuss the effects of 
fiscal policy on the exchange rate, prices, consumption, output and the terms of trade, wherein, the simulation results are set out in Table 2.

Table 2. The long-term effects of fiscal policy on the macroeconomic variables

(a) Long-term effect of fiscal policy on domestic consumption $\left(\partial \hat{C}_{t} / \partial \hat{G}\right)$

\begin{tabular}{ccccc}
\hline \multicolumn{5}{c}{$\alpha$} \\
\hline \multirow{2}{*}{$\alpha^{*}$} & & 0.15 & 0.5 & 0.85 \\
\cline { 2 - 5 } & 0.15 & -0.373 & -0.426 & -0.116 \\
& 0.5 & -0.423 & -0.45 & -0.398 \\
& 0.85 & -1.370 & -0.562 & -0.475 \\
\hline
\end{tabular}

(b) Long-term effect of fiscal policy on foreign consumption $\left(\partial \hat{C}_{t}^{*} / \partial \hat{G}\right)$

\begin{tabular}{ccccc}
\hline \multicolumn{5}{c}{$\alpha$} \\
\hline \multirow{2}{*}{$\alpha^{*}$} & & 0.15 & 0.5 & 0.85 \\
\cline { 2 - 5 } & 0.15 & -0.127 & -0.077 & 0.869 \\
& 0.5 & -0.074 & -0.05 & 0.062 \\
& 0.85 & -0.384 & -0.102 & -0.025 \\
\hline
\end{tabular}

(c) Long-term effect of fiscal policy on world consumption $\left(\partial \hat{C}_{t}^{W} / \partial \hat{G}\right)$

\begin{tabular}{ccccc}
\hline \multicolumn{5}{c}{$\alpha$} \\
\hline & & 0.15 & 0.5 & 0.85 \\
\cline { 2 - 5 }$\alpha^{*}$ & 0.15 & -0.25 & -0.252 & 0.377 \\
& 0.5 & -0.248 & -0.25 & -0.168 \\
& 0.85 & -0.877 & -0.332 & -0.25 \\
\hline
\end{tabular}

(d) Long-term effect of fiscal policy on domestic output $\left(\partial \hat{y}_{h, t}(z) / \partial \hat{G}\right)$

\begin{tabular}{ccccc}
\hline & \multicolumn{4}{c}{$\alpha$} \\
\hline & & 0.15 & 0.5 & 0.85 \\
\cline { 2 - 5 }$\alpha^{*}$ & 0.15 & 0.353 & 0.396 & 0.243 \\
& 0.5 & 0.394 & 0.417 & 0.387 \\
& 0.85 & 1.078 & 0.496 & 0.437 \\
\hline
\end{tabular}

(e) Long-term effect of fiscal policy on foreign output $\left(\partial \hat{y}_{f, t}^{*}(z) / \partial \hat{G}\right)$

\begin{tabular}{ccccc}
\hline & \multicolumn{4}{c}{$\alpha$} \\
\hline \multirow{2}{*}{$\alpha^{*}$} & 0.15 & 0.15 & 0.5 & 0.85 \\
\cline { 2 - 5 } & 0.5 & 0.147 & 0.106 & -0.578 \\
& 0.85 & 0.104 & 0.083 & 0.004 \\
& & 0.257 & 0.113 & 0.063 \\
\hline
\end{tabular}

(f) Long-term effect of fiscal policy on domestic price index $\left(\partial \hat{P}_{t} / \partial \hat{G}\right)$

\begin{tabular}{ccccc}
\hline & \multicolumn{4}{c}{$\alpha$} \\
\hline \multirow{2}{*}{$\alpha^{*}$} & 0.15 & 0.15 & 0.5 & 0.85 \\
\cline { 2 - 5 } & 0.5 & 0.123 & 0.173 & 0.910 \\
& 0.85 & 0.175 & 0.2 & 0.284 \\
& & 0.075 & 0.176 & 0.225 \\
\hline
\end{tabular}


(g) Long-term effect of fiscal policy on foreign price index $\left(\partial \hat{P}_{t}^{*} / \partial \hat{G}\right)$

\begin{tabular}{ccccc}
\hline \multicolumn{5}{c}{$\alpha$} \\
\hline \multirow{2}{*}{$\alpha^{*}$} & 0.15 & 0.15 & 0.5 & 0.85 \\
\cline { 2 - 5 } & 0.5 & -0.123 & -0.175 & -0.075 \\
& 0.85 & -0.173 & -0.2 & -0.176 \\
& -0.910 & -0.284 & -0.225 \\
\hline
\end{tabular}

(h) Long-term effect of fiscal policy on the price of domestic product $z$ denoted in domestic currency $\left(\partial \hat{p}_{h, t}(z) / \partial \hat{G}\right)$

\begin{tabular}{ccccc}
\hline \multicolumn{5}{c}{$\alpha$} \\
\hline \multirow{2}{*}{$\alpha \alpha^{*}$} & 0.15 & 0.15 & 0.5 & 0.85 \\
\cline { 2 - 5 } & 0.5 & 0.397 & 0.351 & 1.552 \\
& 0.85 & 0.358 & 0.333 & 0.499 \\
& & -1.373 & 0.118 & 0.313 \\
\hline
\end{tabular}

(i) Long-term effect of fiscal policy on the price of domestic product $z$ denoted in foreign currency $\left(\partial \hat{p}_{h, t}^{*}(z) / \partial \hat{G}\right)$

\begin{tabular}{ccccc}
\hline \multicolumn{5}{c}{$\alpha$} \\
\hline \multirow{2}{*}{$\alpha^{*}$} & 0.15 & 0.15 & 0.5 & 0.85 \\
\cline { 2 - 5 } & 0.5 & -0.220 & -0.350 & -0.418 \\
& 0.85 & -3.342 & -0.467 & -0.585 \\
& & & -0.966 & -1.223 \\
\hline
\end{tabular}

(j) Long-term effect of fiscal policy on the price of foreign product $z$ denoted in domestic currency $\left(\partial \hat{p}_{f, t}(z) / \partial \hat{G}\right)$

\begin{tabular}{ccccc}
\hline & \multicolumn{3}{c}{$\alpha$} \\
\hline & & 0.15 & 0.5 & 0.85 \\
\cline { 2 - 5 }$\alpha^{*}$ & 0.15 & 0.220 & 0.342 & 3.343 \\
& 0.5 & 0.350 & -0.467 & 0.966 \\
& 0.85 & 0.418 & 0.585 & 1.223 \\
\hline
\end{tabular}

(k) Long-term effect of fiscal policy on the price of foreign product $z$ denoted in foreign currency $\left(\partial \hat{p}_{f, t}^{*}(z) / \partial \hat{G}\right)$

\begin{tabular}{ccccc}
\hline \multicolumn{5}{c}{$\alpha$} \\
\hline \multirow{2}{*}{$\alpha$} & & 0.15 & 0.5 & 0.85 \\
\cline { 2 - 5 } & 0.15 & -0.397 & -0.358 & 1.373 \\
& 0.5 & -0.351 & -0.333 & -0.118 \\
& 0.85 & -1.552 & -0.499 & -0.313 \\
\hline
\end{tabular}

(1) Long-term effect of fiscal policy on exchange rate $\left(\partial \hat{E}_{t} / \partial \hat{G}\right)$

\begin{tabular}{ccccc}
\hline \multicolumn{5}{c}{$\alpha$} \\
\hline \multirow{2}{*}{$\alpha{ }^{*}$} & 0.15 & 0.15 & 0.5 & 0.85 \\
\cline { 2 - 5 } & 0.5 & 0.617 & 0.071 & 1.970 \\
& 0.85 & 0.701 & 0.8 & 1.084 \\
& 1.970 & 1.054 & 1.536 \\
\hline
\end{tabular}


(m) Long-term effect of fiscal policy on terms of trade $\left(\partial T \hat{O} T_{t} / \partial \hat{G}\right)$

\begin{tabular}{ccccc}
\hline \multicolumn{5}{c}{$\alpha$} \\
\hline \multirow{2}{*}{$\alpha{ }^{*}$} & 0.15 & 0.15 & 0.5 & 0.85 \\
\cline { 2 - 5 } & 0.5 & 0.177 & 0.009 & -1.791 \\
& 0.85 & -1.791 & -0.133 & -0.467 \\
& & -0.467 & -0.910 \\
\hline
\end{tabular}

Known by Table 2 (a) to (m), in the long-term, government expenditure and domestic output, domestic price index and the exchange rate exists a positive relationship, while existing negative relationship with domestic consumption; the relationship with the terms of trade will depend on the asymmetric consumption bias behavior of individual between two countries. When the cases of "consumers of both countries have consumption bias on the products produced by competitor country", "domestic consumers have no consumption bias behavior of consumption, but consumers in the foreign country have consumption bias behavior on domestically produced products", and "foreigner does not have consumption bias behavior, but domestic consumers have one on foreign products" are true, government expenditure and the terms of trade are in positive correlation, in the remaining cases, government expenditure and terms of trade are in negative correlation.

The intuition on economy behind the foregoing conclusions can be explained as follows: increase of government expenditure will rise up demand for domestic goods, leading to rise of domestic output and price level, but, due to the "crowding out effect", it results in a decline of private consumption, and reduction of the demand for money, leading to the depreciation of domestic currency (rise of exchange rate), as for the relationship between government expenditure and the terms of trade, it generates uncertain effect by mutual exclusivity of both effects of the rise in prices and exchange rates and it will depend on the asymmetry of consumption bias behavior in both countries.

\section{Conclusion and Suggestions}

Up to now, NOEM has elapsed more than 20 years for development, however, compared to the popularity in the study of effects of monetary shock, those in topic of fiscal shock are rare, in view of the above reasons, this paper takes NOEM model proposed by Obstfeld and Rogoff (1995) as a theoretical framework to integrate consumption home bias into the original model to explore a long-term effects of consumption home bias on macroeconomic variables in the face of fiscal expenditure shock, we also hope that the findings herein can be provided to the relevant authorities as reference for policy-makers.

With the findings of theoretical derivation and simulation analysis, we find that the increased government expenditure will trigger the rise of domestic output, domestic price index and the exchange rate, however, it will drop down the domestic consumption and the relationship between fiscal expenditure and the terms of trade is uncertain, which is depending on the asymmetric behavior of consumers in both countries on the consumption of commodity, when the cases of "consumers of both countries have consumption bias on the products produced by competitor country simultaneously", "domestic consumers have no bias behavior of consumption, but consumers in the foreign country have consumption bias behavior on domestically produced products", and "foreign consumers do not have bias behavior of consumption, but domestic consumers have one on foreign products" are true, the rise of government expenditure will improve the terms of trade.

Finally, it shall be specially noted that, in order to simplify the analysis, this paper only focuses on the long-term analysis, therefore, we did not highlight the dynamic adjustment process of economy, which is one of the limits set herein. Furthermore, NOEM theoretical framework, although has played its significance among each economic issue, in fact, it usually needs to build under a number of assumptions to seek solution easily. If we try to relax one of assumptions or settings (such as the setting of utility function), the results obtained may differ and this deficiency will also be included in the restrictions suffered herein.

\section{References}

Barro, R. J. (1981). Output effect of government purchases. Journal of Public Economy, 89, 1086-1121. http://dx.doi.org/10.1086/261024

Barro, R. J. (1990). Government spending in a simple model of endogenous growth. Journal of Political Economy, 98, S103-S125. http://dx.doi.org/10.1086/261726

Baxter, M., \& King, R. G. (1993). Fiscal policy in general equilibrium. American Economic Review, 83(3), 315-333. 
Bergin, P. R., Shin, H. C., \& Tchakarov, I. (2007). Does exchange rate variability matter for welfare? A quantitative investigation of stabilization policies. European Economic Review, 51(4), 1041-1058. http://dx.doi.org/10.1016/j.euroecorev.2006.05.002

Cooke, D. (2010). Consumption home bias and exchange rate behavior. Journal of Macroeconomics, 32(1), 415-425. http://dx.doi.org/10.1016/j.jmacro.2009.08.001

Corsetti, G., \& Pesenti, P. (2001). Welfare and macroeconomic interdependence. Quarterly Journal of Economics, 116, 421-446. http://dx.doi.org/10.1162/00335530151144069

Dasgupta, D. (1999). Growth versus welfare in a model of nonrival infrastructure. Journal of Development Economics, 58, 359-385. http://dx.doi.org/10.1016/ S0304-3878(98)00127-8

De Paoli, B. (2009). Monetary policy and welfare in a small open economy. Journal of International Economics, 77(1), 11-22. http://dx.doi.org/10.1016/ j.jinteco.2008.09.007

Devereux, M. B., \& Love, D. R. F. (1995). The dynamic effects of government spending policies in a two-sector endogenous growth model. Journal of Money, Credit, and Banking, 27, 232-256. http://dx.doi.org/10.2307/2077861

Dornbusch, R. (1976). Expectations and exchange rate dynamics. Journal of Political Economy, 84(6), 1161-1176. http://dx.doi.org/10.1086/260506

Faia, E., \& Monacelli, T. (2006). Optimal monetary policy in a small open economy with home bias. CEPR Discussion Papers, No. 5522.

Fleming, J. M. (1962). Domestic financial policies under fixed and under floating exchange rates. IMF Staff Papers, 9(3), 369-379. http://dx.doi.org/ 10.2307/3866091

Futagami, K., Morita, Y., \& Shibata, A. (1993). Dynamic analysis of an endogenous growth model with public capital. Scandinavian Journal of Economics, 95, 607-625. http://dx.doi.org/10.2307/3440914

Galí, J., \& Monacelli, T. (2008). Optimal Monetary and fiscal policy in a currency union. Journal of International Economics, 76(1), 116-132. http://dx.doi.org/10.1016/j.jinteco.2008.02.007

Galí, J., Lopez-Salido, D., \& Valles, J. (2007). Understanding the effects of government spending on consumption. Journal of the European Economic Association, 5(1), 227-270. http://dx.doi.org/10.1162/JEEA.2007.5.1.227

Ganelli, G. (2003). Useful government spending, direct crowding-out and fiscal policy interdependence. Journal of International Money and Finance, 22, 87-103. http://dx.doi.org/10.1016/S0261-5606(02)00050-5

Greiner, A. (1998). Fiscal policy in an endogenous-growth model with public investment: A note. Journal of Economics, 68(2), 193-198. http://dx.doi.org/10.1007/BF01237191

Greiner, M., \& Hanusch, H. (1998). Growth and welfare effects of fiscal policy in an endogenous growth model with public investment. International Tax and Public Finance, 5, 249-261. http://dx.doi.org/10.1023/A:1008673925024

Hau, H. (2002). Real exchange rate volatility and economic openness: Theory and evidence. Journal of Money, Credit and Banking, 34, 611-630. http://dx.doi.org/10.1353/mcb.2002.0002

Hillberry, R. H., \& Hummels, D. L. (2002). Explaining home bias in consumption: The role of intermediate input trade. NBER Working Paper, No. 9020.

Jondeau, E., \& Sahuc, J. G. (2008). Optimal monetary policy in an estimated DSGE Model of the Euro area with cross-country heterogeneity. International Journal of Central Banking, 4, 23-72.

Kollmann, R. (2004). Welfare effects of a monetary union: The role of trade openness. Journal of the European Economic Association, 2, 289-301. http://dx.doi.org/10.1162/154247604323067998

Leith, C., \& Lewis, S. W. (2006). The optimal monetary policy response to exchange rate misalignment. Center for Dynamic Macroeconomic Analysis Conference Papers.

Lucas, R. E. (1976). Econometric policy evaluation: A critique. Carnegie-Rochester Conference Series on Public Policy, 1, 19-46. http://dx.doi.org/10.1016/S0167-2231(76)80003-6

Mankiw, N. G., \& Summers, L. H. (1986). Money demand and the effects of fiscal policies. Journal of Money, Credit and Banking, 18(4), 415-429. http://dx.doi.org/10.2307/1992462

Mundell, R. A. (1963). Capital Mobility and stabilization policy under fixed and flexible exchange rates. 
Canadian Journal of Economics and Political Science, 29(4), 475-485. http://dx.doi.org/10.2307/139336

Obstfeld, M., \& Rogoff, K. (1995). Exchange rate dynamics redux. Journal of Political Economy, 103, 624-660. http://dx.doi.org/10.1086/261997

Obstfeld, M., \& Rogoff, K. (2000). The six major puzzles in international macroeconomics: Is there a common cause? In B. S. Bernanke, \& K. Rogoff (Eds.), NBER Macroeconomics Annual (Vol. 15, pp. 339-390). http://dx.doi.org/10.1162/08893360052390428

Pesenti, P., \& Van Wincoop, E. (2002). Can nontradables generate substantial home bias? Journal of Money, Credit, and Banking, 34(1), 25-50. http://dx.doi.org/10.1353/mcb.2002.0034

Pierdzioch, C. (2004). Home-product bias, capital mobility, and the effects of monetary policy shocks in open economies. Kiel Working Paper, No. 1141.

Pitterle, I., \& Steffen, D. (2004a). Fiscal policy in a monetary union model with home bias in consumption. Mimeo, University of Frankfurt.

Pitterle, I., \& Steffen, D. (2004b). Spillover effects of fiscal policy under flexible exchange rate. Working Paper, University of Frankfurt.

Ried, S. (2009). Putting up a good fight: The Galí-Monacelli model versus "the six major puzzles in international macroeconomics”. SFB 649 Discussion Papers, Humboldt University, Berlin, Germany.

Schmidt, C. (2006). International transmission effects of monetary policy shocks: Can asymmetric price setting explain the stylized facts? International Journal of Finance and Economics, 11, 205-218. http://dx.doi.org/10.1002/ijfe.293

Stockman, A. C., \& Dellas, H. (1989). International portfolio nondiversification and exchange rate variability. Journal of International Economics, 26, 271-289. http://dx.doi.org/10.1016/0022-1996(89)90004-4

Sutherland, A. (2005). Incomplete pass-through and the welfare effects of exchange rate variability. Journal of International Economics, 65, 375-399. http://dx.doi.org/10.1016/j.jinteco.2004.01.005

Tervala, J. (2008). Productive government spending, welfare and exchange rate dynamics. Financial Theory and Practice, 32, 97-114.

Uhlig, H. (1995). A toolkit for analyzing nonlinear dynamic stochastic models easily. Center for Economic Research Discussion Paper, No. 97, Tilburg University.

Wang, J. (2010). Home bias, exchange rate disconnect, and optimal exchange rate policy. Journal of International Money and Finance, 29, 55-78. http://dx.doi.org/10.1016/j.jimonfin.2008.12.010

Xie, D., Zou, H. F., \& Davoodi, H. (1999). Fiscal decentralization and economic growth in the United States. Journal of Urban Economics, 45, 228-239. http://dx.doi.org/10.1006/juec.1998.2095

\section{Notes}

Note 1. The six puzzles proposed by Obstfeld and Rogoff (2000) are consumption home bias puzzle, home bias in equity portfolios puzzle, purchasing power parity puzzle, exchange rate disconnect puzzle, the high investment-saving correlation puzzle, and the low international consumption correlation puzzle.

Note 2. In Eq. (1), $\varepsilon$ is defined as a proportion of marginal utility of real money demand change raised by $1 \%$ change of the real money demand.

Note 3. Because of the complexity of the model setting, in order to obtain a closed-form of solution between exogenous variables and endogenous variables, two ways were more frequently used in the literature: $\log$-linearization and numerical simulations. Our model is to use log-linearization incorporated with numerical simulation.

\section{Copyrights}

Copyright for this article is retained by the author(s), with first publication rights granted to the journal.

This is an open-access article distributed under the terms and conditions of the Creative Commons Attribution license (http://creativecommons.org/licenses/by/3.0/). 